\title{
Border-Crossing Female Artists Between Experimental and Popular Music From 1970 to the Present Day in Serbia and Bosnia \& Herzegovina
}

\author{
Marina Vesic-Eder \\ Composer-pianist, avant-garde artist \\ Vienna, Austria \\ vesicmarina@mdw.ac.at
}

\begin{abstract}
The goal of my paper for EVA London 2020 (Electronic Visualisation and the Arts) is to provide insights about female Serbians and Bosnia \& Herzegovina artists who have crossed stylistic boundaries between popular, experimental and electronic music coming from different backgrounds. In this paper, focusing on several specific artists, I will analyse their significant contributions to different music genres and artistic developments throughout the decades. This paper aims to focus on collecting significant data about the diverse Serbian and Bosnia \& Herzegovina artists who were both influenced by different genres, and also influenced others themselves.
\end{abstract}

Border-crossing female artists. Performance in music. Performance in art. Storytelling. Digital technology in electronic music.

\section{INTRODUCTION}

This paper represents my plan of ongoing research in the field of experimental and popular music, including a list of Serbians and originated Yugoslav female artists who are also well known internationally. The main focus is on the female artists such as Milica Paranosic, Svjetlana Bukvich, Alexandra Sladjana Milosevic, Ana Milosavljevic, Lene Lovich as musicians, and Marina Abramovic as a role model in performance art. International influences will also be considered.

Diaspora and migration terminology are of a huge importance to this research, as discussed in a key reference for this study by Alenka-Barber Kersovan in her article Rock den Balkan! (2006). Here, she describes Balkan as an emotional territory. Her theories of diaspora, migration and mixing culture will also be discussed.

The methods of this research are based on historical research, social network analysis, musicological analysis, which includes storytelling and performance, and interviews. The main questions are: (i) Which aspect of the pre- and post-war history of former Yugoslavia influenced the Serbians and Bosnia \& Herzegovina art scene (diaspora terminology, migration, as well as Western - Balkan mixing style)?

(ii) What is the importance of female Serbians and Bosnia \& Herzegovina artists in the field of diverse crossover, and how do they use their music, literature and performance to tell their stories?

One of the methodological aspects will also be focusing on social network analysis, as well as storytelling as an approach in performance.

\section{THEORETICAL FRAMEWORK}

I will focus on several female Serbian and Bosnia \& Herzegovina artists, who have marked a period in a music history of former Yugoslavia.

\section{Marina Abramovic}

First, it is interesting to see that today the wellknown pop icon Lady Gaga was influenced by 
Serbian performance artists Marina Abramovic. These two artists collaborated in 2013 , on the Lady Gaga album Artpop.

\section{Milica Paranosic}

Another very important piece, the one-woman multimedia show Confessions by Milica Paranosic (first performance was in 2008 in New York), was partly influenced by the electronic minimal music of Laurie Anderson. These similarities can be heard in Paranosic's musical performances.

\section{Svjetlana Bukvich}

Svjetlana Bukvich was influenced by Kate Bush, although in her remarkable and important music piece Before and After the Tekke, we can hear the diverse of crossover musical styles, traversing New York to Bosnia \& Herzegovina, and back again, via the combination of Balkan style with hip hop beats as well as using electronics such as the Moog synthesizer.

\section{Alexandra Sladjana Milosevic}

Alexandra Sladjana Milosevic is Serbian pop-punk icon and in her music could be heard influences of German singer Nina Hagen. The influence of Diamanda Galas and Lydia Lunch will be a future topic of investigation.

\section{Lene Lovich}

Lene Lovich collaborated with Nina Hagen on a song called Don't Kill the Animals.

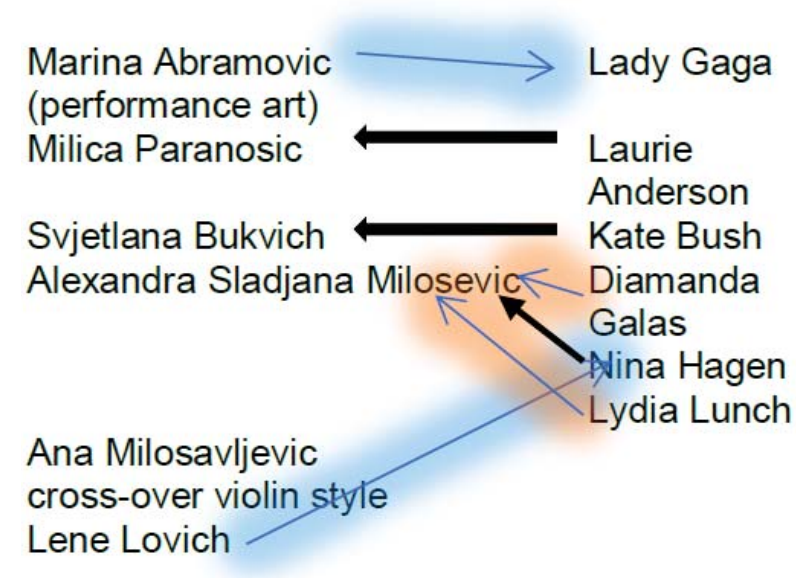

Figure 1: International influences.

In the Figure 1 we can see the influences of these artists. Storytelling is one of the approaches that we can use for analysing music performance, and through this we may consider that many of these five female artists use ex-Yugoslavian literature or some of the old traditional Balkan songs, combing them with electronics. A key work of literature is the book The Death and the Dervish by Bosnian writer Mesa Selimovic. This book was an inspiration for a composition of Svjetlana Bukvich Before and After the Tekke, which brought her a lot of success. Today, Svjetlana Bukvich is one of the twenty most successful female composers in the USA.

\section{DIASPORA AND MIGRATION}

During the war in ex-Yugoslavia in the 1990s, lots of artists migrated into different countries. According to my collected data, the musicians Milica Paranosic, Svjetlana Bukvich, and Ana Milosavljevic left mostly at the same period as they got scholarships for further study in New York. As we can see in Table 1 below, Lene Lovich's parents migrated in the 1940s, in connection with the war that was happening in former Yugoslavia. My research so far suggests that Alexandra Sladjana Milosevic was in Los Angeles for collaboration and work, and she went back to Belgrade during the 2000s. Marina Abramovic is the oldest one, and so left the country first. Her very first performance was in the UK, in Edinburgh in 1973.

The artists that I have interviewed didn't leave because of what was happening in their countries, they left to develop themselves more and therefore it was a huge challenge as well. If I self-reflect on this subject, I have left my country too, in 2011, but also for reasons of artistic development. Therefore, I see ta connection between my chosen female artists and myself. Marina Abramovic moved to New York in 2001 where she founded her Institute MAI, but in 2019 she moved to London, according to the last information which was provided on the website.

Table 1: Migration

\begin{tabular}{|c|c|}
\hline $\begin{array}{l}\text { Marina Abramovic } \\
\text { (performance art) }\end{array}$ & $\begin{array}{r}\text { left her country in the } \\
\text { 1970s, moved to New } \\
\text { York in } 2001, \\
\text { moved to London in } \\
2019\end{array}$ \\
\hline Milica Paranosic & $\begin{array}{l}\text { left in } 1994 \text { to New } \\
\text { York, USA }\end{array}$ \\
\hline Svjetlana Bukvich & $\begin{array}{r}\text { left in } 1992 \text { to New } \\
\text { York, USA }\end{array}$ \\
\hline Lene Lovich & $\begin{array}{l}\text { migration parents } \\
\text { with } \mathrm{BIH} \text { heritage }\end{array}$ \\
\hline $\begin{array}{r}\text { Alexandra S. } \\
\text { Milosevic }\end{array}$ & $\begin{array}{r}\text { left in } 1990 \text { to Los } \\
\text { Angeles, returned to } \\
\text { Belgrade in the } \\
2000 \mathrm{~s}\end{array}$ \\
\hline Ana Milosavljevic & $\begin{array}{l}\text { left in } 1993 \text { to New } \\
\text { York, USA }\end{array}$ \\
\hline
\end{tabular}




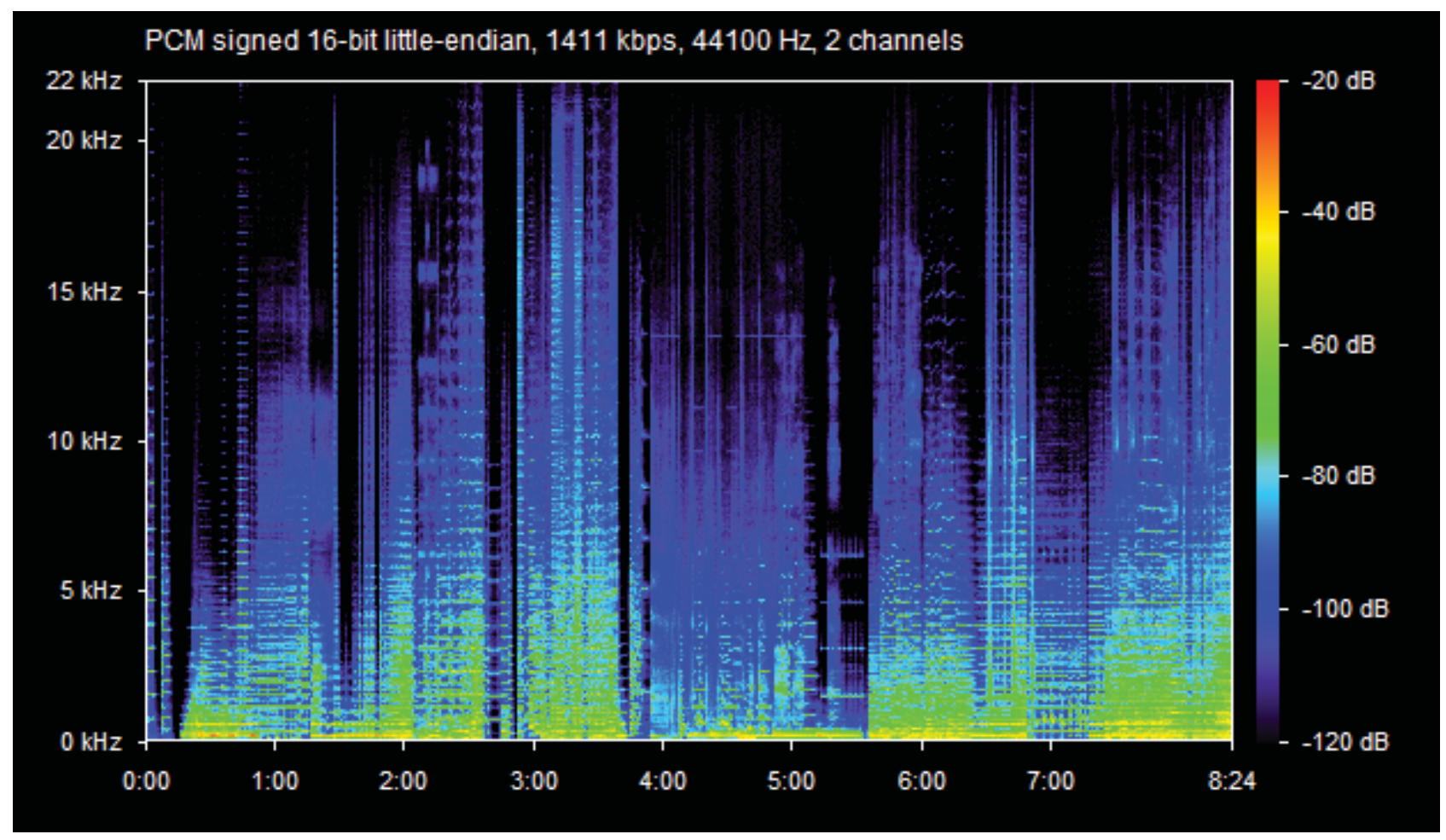

Figure 2: Sonogram of electroacoustic piece 'Before and After the Tekke' by Svjetlana Bukvich.

\section{STORYTELLING AND PERFORMANCE}

\subsection{Confessions}

Analysing works from the chosen artists allows us see how storytelling can lead to different approaches. Here I shall discuss the performance Confessions by Milica Paranosic. This is a unique one-woman multimedia show, where the composer is also as a performer, combining Balkan music with electronic music using her own samples made in the music program Logic. She is also using live electronics in this performance. The story is autobiographical, and it tells us a story spanning from when she was a child, to her present day, which can be seen on the screen behind her. This is a wonderful journey through different periods of her life. The very first bars come from a traditional Macedonian song Kales bre, Andjo, which she interprets in a modern style:

I have chosen this song, because it was one of the favourites of my dad, who passed away.

This song comes from a time of Ottoman Empire and the story is about a young woman who was proposed to by a Turkish man. He offers her gold and a rich life, but she denies the offer, telling him that she doesn't want to take his religion and to change herself. This narrative story seems to reflect true social events in the Balkan.
It seems that all the Balkan happenings, not only during the 1990s, but also earlier, have inspired composers to add some musical elements from their hometowns. This is also the case with the performance by Marina Abramovic, Balkan Baroque. There, we have a real story too, but this time it is about a particular time during the war in 1993, where she speaks about the rats that she saw in her building in Belgrade. As she wasn't in Belgrade at that time, she made this performance. It consists of bones. Behind the artist we can see images of her parents, and we see Marina Abramovic washing the bones. Balkan happenings have affected not only the Balkan artists, but international ones as well, as we see in the collaboration between Lady Gaga and Marina Abramovic.

\subsection{Before and After the Tekke}

We can now turn to consider Svjetlana Bukvich's Before And After The Tekke. The very first ideas for this composition, regarding experimentation with rhythm and instrumentation, were born during 1992-1994 when Svjetlana Bukvich did her postgraduate studies at Rensselaer Polytechnic Institute, M.F.A. More about the artist can be read in a book by Jennifer Kelly, In Her Own Words: Conversation with Composers in the United States (2014). 
The composition includes lyrics from the book The Death and the Dervish by Mesa Selimovic, which was an inspiration to this remarkable work:

Without you, the foreign, distant lands hurt more and the empty roads and the strange dreams that I have even when I am awake that I can't chase away without you.

The connection between electronics and violin is organic in the piece. Where one begins, the other ends, and it is very important to look at the violin as an integral part of the Moog vice versa! Violin clenching is also present in electronics, and $G$ is tempered everywhere, as a constant - something a listener can get hold of. In these aspects of her creation, she always draws the audience into the new, but also takes care of it, giving them something familiar and compelling, so that they feel comfortable when confronted with the new and unknown.

This work is constructed in three parts. The first part represents New York and space, and the third part reflects metaphysics, and the sublimation sounds of New York, old Europe, and ethno-magic realism. This part also reflects a willingness to fight and research the universe, and one's own, unimposed, spirituality.

Between these parts, the middle section is peace, creating a timeless space. Breathing is the entry into synchrony with nature and multidimensionality of time. Herzegovina has a great deal to do with this piece. The violin and the analog Moog synthesizer can play microtonally. In unison, they create the sound of the present and the past united.

This work represents the composer's travel before and after her visit tekke on the river Buna in Bosnia and Herzegovina. It represents a spiritual journey across New York - Bosnia \& Herzegovina - New York. The premiere of this piece was in New York in 2008, and it is on the composer's solo album Evolution, from 2014. On this piece her collaborating musicians were Cornelius Dufallo and Tony Levin. Svjetlana Bukvich played drums tracks, SFX, Minimoog synthesizer, voice and altered tuning design.

Svjetlana Bukvich's style is unique. She works with musicians from different backgrounds and with expertise in different genres sharing intimate space of composition. By mixing genres she mixes histories. In her works we can hear a mix of progressive, eclectic, electro-acoustic, classical and jazz sound mixed with Balkan influences.

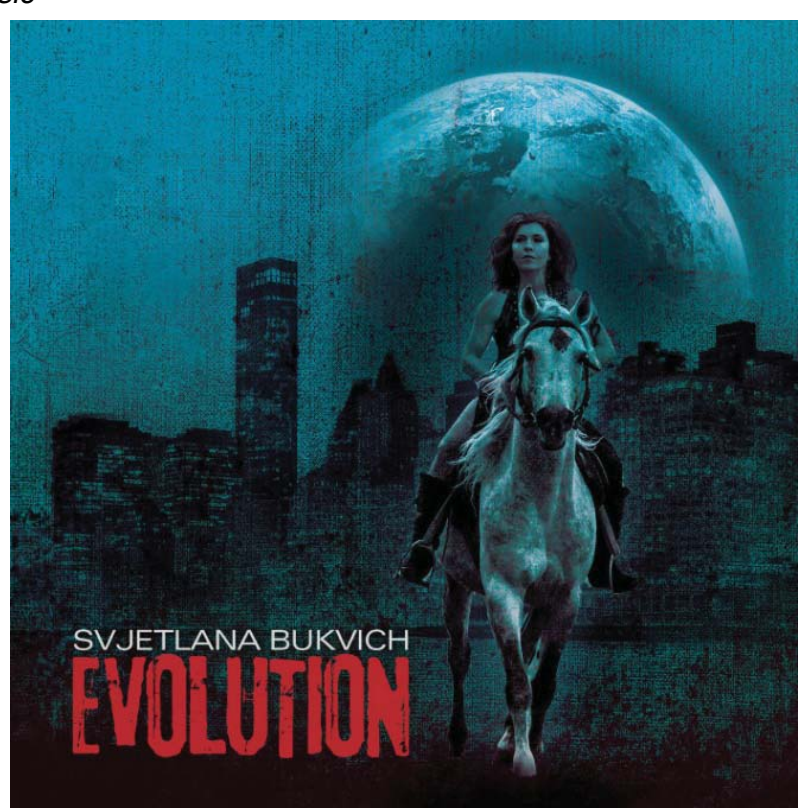

Figure 3: Svjetlana Bukvich - Evolution (CD cover).

Bukvich is currently a board member of the American Festival of Microtonal Music and the Bosnian-Herzegovinian American Academy of Arts and Sciences, associate director of the new music presenting organisation Composers Concordance, and an honouree in Selected Honours, Awards \& Achievements in American Society of Composers, Authors and Publishers (ASCAP) Concert Music. She is an Assistant Professor at City University of New York, and has previously held positions as Adjunct Professor at Pratt Institute and New York University (NYU). She is a contributing author in the magazine Modern Diplomacy International and in the book Perspectives on Music Production: Gender in Music Production to be published by Focal Press, Francis and Taylor, United Kingdom, in fall of 2019.

\section{CONCLUDING REMARKS}

Digital technology over the past 50 years has definitely influenced the output of the chosen artists, who I have examined in this paper. In the domain of experimental music, these female artists use their laptops and samples in their compositions. Technology is a part of their art, especially today, since it allows for the recording of music, and makes promoting it possible through social media. The huge development in technology over the last 50 years has had a considerable effect and impact of the compositional process, including my own experience as a composer and performer. 


\section{REFERENCES}

Abramovic, Marina (1997) Balkan Baroque [multimedia work].

Abramovic, Marina (2010) The Artist is Present, Museum of Modern Art.

Abramovic, Marina (2020) Wikipedia [Internet resource].

https://en.wikipedia.org/wiki/Marina_Abramovi\%C4 \%87 (retrieved 20 March 2020).

Archive Radio Television of Serbia.

Barber-Kersovan, Alenka (2006) Rock den Balkan! Die Musikalische Rekonstruktion des Balkans als emotionales Territorium, in: Beiträge zur Popularmusikforschung 34, Hg.v. Helms, D. Und T.Phleps, Cut and paste: Schnittmuster populärer Musik der Gegenwart, Bielefeld.

Bukvich, Svjetlana (2008) Before and After the Tekke [musical work].

Bukvich, Svjetlana (2020) Artist website [Internet resource]. http://www.svjetlanamusic.com/ (retrieved 20 March 2020).

Hornberger, Barbara (2013) Der dokumentarische Gestus. Eine Spurensuche in populaerer Musik und Kultur in der BRD der 1970er Jahre, in: Helms, Dietrich und Thomas Phleps (Hg.): Ware Inszenierungen - Performance, Vermarktung und
Authentizitaet in der populaeren Musik, Beitraege zur Popularmusikforschung 39, Bielefeld.

Interviews with the artists, carried out by the author.

Huber, Harald (2007) Stilgeschichte der Popularmusik im Ueberblick, mdw.

Janjatovic, Petar (1960-2006) EX-YU Enciklopedija.

Lovich, Lene (1979) Bird Song [musical work].

Milosavljevic, Ana (2011) Zajdi, Zajdi [musical work].

Milosavljevic, Ana (2020) Artist website [Internet resource]. http://www.anamilo.com/ (retrieved 20 March 2020).

Milosevic, Alexandra Sladjana (2000) Legalize Freedom [musical work].

Milosevic, Alexandra Sladjana (2020) Artist website [Internet resource].

http://www.sladjana.com/pages/news.htm (retrieved 20 March 2020).

National Television of Serbia (RTS).

Paranosic, Milica (2008) Confessions [multimedia work].

Paranosic, Milica (2020) Artist website [Internet resource]. https://www.milicaparanosic.com/ (retrieved 20 March 2020). 